\title{
The Impact of the Finalization of the China-Holy See Deal in 2018 to the Catholic Community in China
}

\author{
Hengshi An
}

\author{
Georgetown Preparatory School, Rockville, 20852, USA \\ *Corresponding author. Email: angela@cas-harbour.org
}

\begin{abstract}
In Catholic tradition, the ordinations of clergy have to be approved by the Pope. However, many early ordinations in China had been supervised by the government. How could these ordinations and Masses be valid? This had concerned many Chinese Catholics before the 2018 China-Holy See Deal, which provided a solution, but still provoked debates. This essay studies if the 2018 Deal will de facto benefit the ordinary Chinese Catholics. An analytical study and a comparative study was conducted in this essay, which included the reference of sources quoted from the various sides of the debate and analysis of the key published resources regarding to this topic. Also, interviews with the witnesses of this issue, including the members of the underground church in China and the state church priests who were studying abroad, were referred in this study. This essay sought to predict a potential future of the Catholic community in China, and through this particular case, offers an alternative to the universal question of the role of religion in a state. The studies also lead to the conclusion that mutual compromise between China and the Holy See is probably the most beneficial for the ordinary Catholic population in China under the current situation.
\end{abstract}

Keywords: Catholic community, China-Holy See Deal, religion

\section{INTRODUCTION}

"There must be relations between our Church and the Government because we live in this political reality; consequently, it is good to have lines of communication."-Pope Benedict XVI [1].

The quote was originally included in Pope Benedict XVI's letter to the Church in China in 2007, but was later deleted from the original letter as Cardinal Joseph Zen protested, a major opposition of the state church in China, that the line "seems to imply that we must keep the CPCA, but this is not appropriate".

The quote under the title was taken from the draft of Pope Benedict XVI's famous letter to the Church in China in 2007 [8]. Although it was eventually deleted from the published letter, this line properly indicated a possible future for the Catholic Church in China: a well-established and functioning community that both the Vatican and the Chinese government would be satisfied with. This prediction of such a future was drawn by the history of the Holy See-China relationship, which involved lots of obstacles and compromises.

The situation of the Catholic Church in China is very complicated, but it is not an individual case. Many countries around the world had or are still having troubles establishing a religion's status in society, or even in the country's politics. For example, many people in the United States are still suspicious of the Catholic politicians; China's policies of Muslims and the Tibetan Buddhists are still controversial; And the situation of minority religions in the Islamic countries is also problematic. As a result, by looking at the case in China, it gives an idea of how modern governments can deal with the religion. Furthermore, if it works in China, it may set an example for the future of religion in the world's lay society. Therefore, this essay analyzes the current situation of the Catholic community in China and how the changing relationship between China and Vatican City would impact this community.

\section{BACKGROUND}

\subsection{The background of China-Holy See deal}

During the papacy of John Paul II (1978-2005), the Church started delicate negotiations with China on the status of the underground Church in China and of the Chinese Patriotic Catholic Association (CPCA) in the world (The official website of the CPCA describes itself as it was "formed in 1957 by the Catholic population in China as a patriotic non-profit public organization". It is the official organization approved by the government to supervise the Catholic Church in China). Yet, significant progress did not occur until the papacy of Pope Francis in 2018. On September 22nd of that year, China and the Vatican signed a historic agreement concerning episcopal appointments in China. This agreement was seen as a big step towards the overall normalization of the China-Holy See relationship which had been ruptured since 1949 . However, while the historic nature of this pact was undeniable, not everyone viewed the agreement as a positive development. For 
example, Cardinal Joseph Zen of Hong Kong, who also happens to be a personal friend of Pope Benedict XVI, was a major opposition figure to the deal. He believed that no compromise should be made until the humanitarian situation in China has been improved. In other words, he argued that it was premature to make this pact and it would not serve the interests of the church in China in the longterm.

The most serious conflict between the Chinese government and the Church concerns episcopal appointments. It is directly stated in the Constitution of China that "Religious bodies and religious affairs are not subject to any foreign domination [6]." The bottom line of the PRC was that the bishops should be appointed by the CPCA, whereas the Holy See had always maintained that the bishops only be appointed by the Pope. The episcopal appointment led to the issue of the legitimacy of the bishops, which directly related to every Catholic in China: if the bishop was not legitimate, would the priest who was appointed by him be legitimate? And what about the masses if this priest had celebrated, would they be legitimate? There were many bishops that had been ordained by the CPCA but were not approved by the Pope. Therefore, the biggest concern of the CPCA church members was the legitimacy of the masses they had attended.

\subsection{The overview of the China-Holy See Deal}

As the Church was seeking for more talks with the PRC, the problem was gradually solved. Under the Papacy of Pope Benedict XVI, the Congregation for the Doctrine of the Faith (CDF) concluded that "there are no reason to say that the bishops ordained by the CPAC are invalid; that is to say, although illegitimate, they were valid. Consequently, the priests ordained by these bishops were also validly ordained and their Masses were also true Masses [3]." This clarification was a significant progress in the development of the China-Holy See deal. On September 22nd, 2018, the PRC and the Vatican agreed that each parish could pick one to two candidates which they presented via diplomatic channels to the Papacy. If both sides have approved the candidate, then he could be consecrated as a bishop. The author had a chance to talk to some of the Chinese exchange students at the Catholic University of America, which most of them were deacons and priests of the CPAC churches. In the interviews with these Chinese clergies in the US, they expressed that their parishioners' biggest concern was the Eucharist they had received. Was the bread and wine consecrated by a legitimate and valid priest? This had troubled many parishioners. Four days after the Deal was signed, Pope Francis published the "Message of Pope Francis to the Catholics of China and to the Universal Church, 26.09.2018" on the Vatican Press Bulletin. In the Message, Pope Francis that "for the sake of supporting and promoting the preaching of the Gospel in China and reestablishing full and visible unity in the Church, it was essential, before all else, to deal with the issue of the appointment of bishops [10]." He made the recession and admitted that some clergies had served as a symbol of imperialism and exploitation in the history of China by describing that "the recent history of the Catholic Church in China has been marked by deep and painful tensions, hurts and divisions, centred especially on the figure of the bishop as the guardian of the authenticity of the faith and as guarantor of ecclesial communion [10]." He also pointed out that the biggest hope for the ordinary Chinese Catholics at the moment was "the heartfelt desire to live their faith in full communion with the universal Church and with the Successor of Peter, who is "the perpetual and visible source and foundation of the unity both of the bishops and of the whole company of the faithful" (SECOND VATICAN ECUMENICAL COUNCIL, Dogmatic Constitution Lumen Gentium, 23) [10]." Eventually, in the Message, Pope Francis explained the part of the Deal that directly addressed the ordinations of the Chinese bishops: "Consequently, after carefully examining every individual personal situation, and listening to different points of view, The author has devoted much time to reflection and prayer, seeking the true good of the Church in China. In the end, before the Lord and with serenity of judgment, in continuity with the direction set by immediate predecessors, the author has determined to grant reconciliation to the remaining seven "official" bishops ordained without papal mandate and, having lifted every relevant canonical sanction, to readmit them to full ecclesial communion. At the same time, the author asked them to express with concrete and visible gestures their restored unity with the Apostolic See and with the Churches spread throughout the world, and to remain faithful despite any difficulties [10]." As Pope Francis had pointed out, the Deal indeed promoted "the shared hope is that this agreement may favour a fruitful and forward-looking process of institutional dialogue and may contribute positively to the life of the Catholic Church in China, to the common good of the Chinese people and to peace in the world [9]."

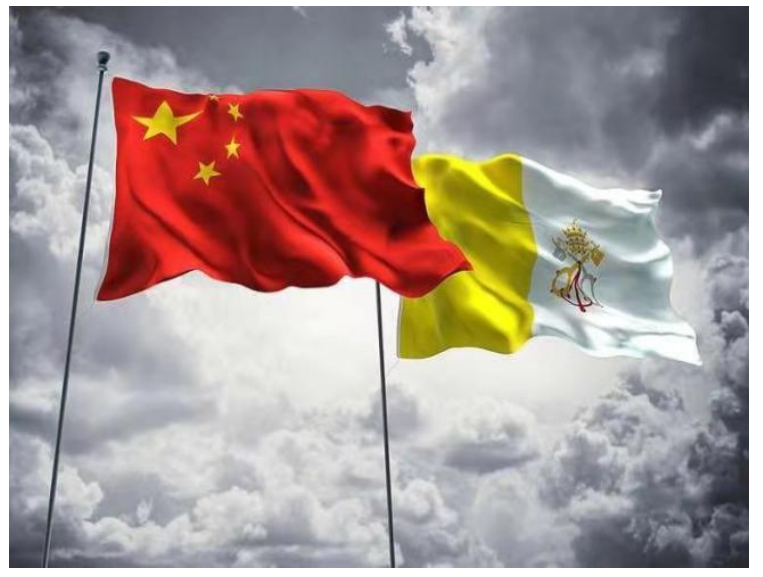

Figure 1.The flags of the People's Republic of China and Vatican City (Credit: FreshStock/Shutterstock.)

Once the final agreement between the PRC and Vatican City has been made, there will hopefully be a mutually satisfactory arrangement between the Chinese government and the Church. This would include a well-established system of the appointment and approval of the bishops that 
can be based on the rules of the 2018 Deal. Since the bishops will be regarded as "valid" by the underground church, there then will be no reason for them to stay "underground". This will lead to the unification with the government-supported CPCA Church in China. The unification would potentially reap tremendous benefits for the current underground church. In an interview with the members of a local Shanghai underground church, they explained their disadvantages of being "underground" as they had to do everything secretly. They refused to tell the exact address of their church, which was hidden in an inconspicuous apartment building. In this underground setting, the members expressed their desire to be able to hold public masses as the CPAC churches do. Through the 2018 Deal and the fixed relationship between China and the Vatican City, hopefully, this unification will come true in the near future.

\section{THE DEAL IN A LAITY PERSPECTIVE}

Throughout the world, many countries have struggled to find a balance between lay rule and religious influence. Regarding to Catholicism, the situation is especially tricky, and yet, universal. The Church's supre-governmental element and its absolute loyalty to the Pope makes it very problematic to the governments. Even for countries like the United States, who puts religious freedom as a core value of the nation, had problems establishing the status of the Church in the country. The anti-Catholicism in the 19th century, and the phenomenon that there was not a single Catholic president until JFK are both based on suspicion towards the "independence" of Catholicism. Due to the imperialism background in China, Chinese people are especially suspicious of the Church. As the first Premier of the PRC, Chou En-lai had pointed out, "In the previous century, the preaching of Christianity and its impact on the Chinese culture, is associated with the invasion of imperialism in China......Therefore, Chinese people had a very bad impression towards Christianity, (we) call it 'foreign religion', believe that Christianity is almost the same as imperialism invading China, and thus against Christianity [2]." That is why many people in China are naturally hostile against the Church and are not comfortable with the idea of a domestic institution being loyal to a foreigner. Moreover, as the author had mentioned earlier in the paper, the Chinese Constitution directly forbids any domestic religion to be subjected to any foreign domination. Therefore, it was not wise for Vatican City to take too drastic actions like martyring the 120 Catholics who had died in China (many of them died during the Boxer rebellion, an action that the CPCA has always attacked as "colonialist interference" by the Holy See) [5]. Instead, compromise should be the way to ease the tension between Vatican City and China, at least for the sake of the situation of the Chinese Catholic population. And the 2018 Deal was a great compromise between the Church and the Chinese government which is based on mutual respect and cooperation. In additon, this was probably the best solution for the Catholic community in China. As Professor Liu
Qian, an expert on the study of religion in China, had stated in his book that "through reforming the Catholic Church in China into a more independent religion (from the Vatican City)", people can gradually reduce their hostility towards the Catholics in China [2]. And by that, the biggest beneficiary, accordingly, is the ordinary Catholic believers.

\section{OPPOSING VOICES OF DEAL}

Although the deal was embraced by many Catholics and the lay society in China, there were still opposing voices. The primary opponents of the China-Holy See deal, led by the former Cardinal of Hong Kong, Joseph Zen, are Catholics living in Hong Kong and overseas. Many of them often have ties or even experience with the Chinese anti-Catholic policies since 1950 .

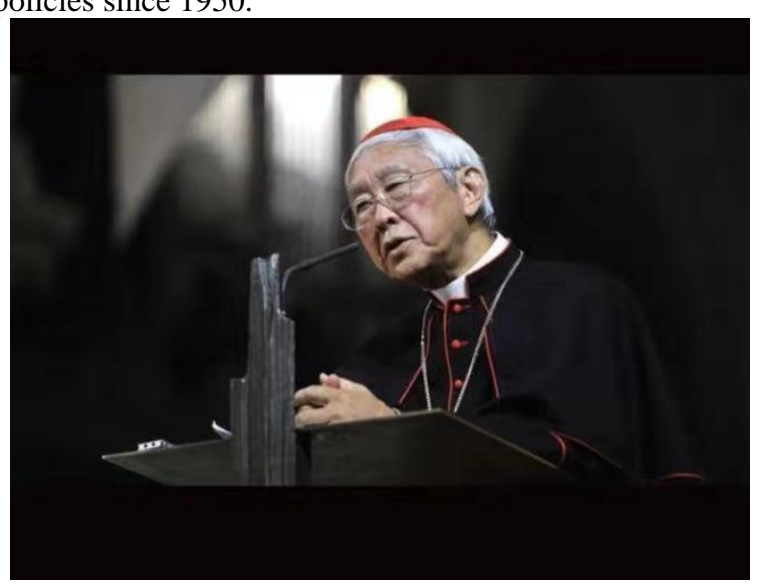

Figure 2. Cardinal Zen: Compelled to Speak

(Cropped book cover of "For Love of My People I Will Not Remain Silent On the Situation of the Church in China")

Although the deal had a less direct impact on them comparing to the Catholics in mainland China, their main concern was about the humanitarian situation in China. They were worried about the future of the underground church especially that once the deal had been made, they would lose their leverage. Also, due to the environment of those Western countries they live in, they could be more idealistic rather than practical and therefore focused on what was possible rather than what was realistic. In Cardinal Zen's book For Love of My People I Will Not Remain Silent, he believed that the act of the Church negotiating with the Chinese government was naive. He condemned that "Our high-ranking Vatican officials, most of whom are Italian, have not lived under such a totalitarian regime, so their concept of it is somewhat naive and optimistic [3]." He also believed that due to the South American background of Pope Francis, he was likely to be sympathetic towards Communism. Cardinal Zen, who was one of the leaders of the Hong Kong "Occupy Central with Love and Peace" movement in 2013, was also known as an anti-communist. He believed that no compromise should be made unless the humanitarian situation in China has been 
improved. He was afraid that once the deal has been made, it would bring the underground church under the supervision of the government at the same time. That is why he also emphasized in his book that the parishes must be led by the bishops instead of the government. He also criticized the CPCA for being the barrier in the unification of the two churches in China. He claimed that if all the underground church members make their identity public today, they will be arrested by the government immediately, and that is one thing the CPCA wants to see.

However, there are still doubts about Cardinal Zen's evidence for his hypothesis. Yet when he was visiting Washington DC in 2017, the author had a chance to meet him in person, the author directly asked him about this quote in his book. He answered that, "I had taught in a seminary in mainland China, I saw that there are a great number of the faithfuls, they are the hope of the Evangelization in this country. There is no reason why we should commit suicide now." Though these are dramatic words, Cardinal Zen's stand is very clear. Due to his background as an anti-communist, and his participation in anti-government activities, it is necessary to consider his bias towards the Chinese government. It might even be reasonable to assume that his intentions are not purely religious-perhaps he is using religion for political purposes? Since his opposition against the CPCA was a direct violation against the Chinese Constitution [7].

\section{DISCUSSION}

The author's curiosity towards the validity of Chinese clergies began in 2018 when the author saw the news about Vatican City legitimizing eight Chinese bishops. In order to figure out the advantages and disadvantages of the deal, the author did the study during the summer break through a thorough research on the issue and gained insight into the issue by referring to more resources beyond the news articles, and interviewed the clergies from the US and the underground churches in China.

Since the issue contains split opinions, which in China, there was the argument of recognizing the status of the Roman Catholic Church in the country is unconstitutional, while in the Vatican City, there was an opposing power who puts politics above theology when considering the details of the deal, both sides showed biased perspectives towards the issue, therefore, in order to develop my essay and make an objective and informative case, the author had to view the different arguments with an academic attitude and try to avoid my own perspectives.

\section{CONCLUSION}

So what is the future of the Catholic community in China? Since the deal of 2018, some real progress has been made. Therefore, for the special political and historical situation in China, and the complicated religious situation, mutual compromise between China and the Holy See is probably the most beneficial for the ordinary Catholic population in China. However, there are still more talks for the two sides to do to finalize a mutual agreement. Quoting Saint Paul, "...you may be filled with the knowledge of his will... (and) strengthened with power, according to his glorious might, for all endurance and patience" $(\mathrm{Col} \mathrm{1:9,11)} \mathrm{[4].} \mathrm{What} \mathrm{is}$ the future of the Catholic community in China? Since the deal of 2018, some real progress has been made. Therefore, for the special political and historical situation in China, and the complicated religious situation, mutual compromise between China and the Holy See is probably the most beneficial for the ordinary Catholic population in China. However, there are still more talks for the two sides to do to finalize a mutual agreement. Quoting Saint Paul, "...you may be filled with the knowledge of his will... (and) strengthened with power, according to his glorious might, for all endurance and patience" $(\mathrm{Col} \mathrm{1:9,11)} \mathrm{[4].}$

\section{ACKNOWLEDGMENT}

First and foremost, I would like to show my deepest gratitude to my teachers and professors in my university, who have provided me with valuable guidance in every stage of the writing of this thesis. Further, I would like to thank all my friends and roommates for their encouragement and support. Without all their enlightening instruction and impressive kindness, I could not have completed my thesis.

\section{REFERENCES}

[1] The Chinese Catholic Patriotic Association, cardinalkungfoundation.org/ar/ChineseCatholicPatrioti cAsso.php.

[2] Liu, Qian. Religion and National Security in the Post-Cold War Era. China Social Science Press, 2017.

[3] Zen, Joseph. For Love of My People I Will Not Remain Silent. Ignatius, 2018.

[4] Holy Bible, Catholic Book Pub. Co., 1987.

[5] The Problem of the 120 Matyrs, The United Front Department of CCCP, [Online] Available: http://tyzx.people.cn/n/2014/0508/c372202-

24992254.html [Accessed on November 15, 2019]

[6] Li Su, Da Guo Xian Zheng, The Constitution of China, Peking University Press, 2018.

[7] Qianfan Zhang, The Constitution Of China: a Contextual Analysis, Hart-2012.

[8] EXPLANATORY NOTE, Letter of His Holiness Pope Benedict XVI to Chinese Catholics, May 27, 2007.

[9] Provisional Agreement between Holy See and China, September 22nd, 2018, [Online] Available: 
https://www.vaticannews.va/en/vaticancity/news/2018-09/china-holy-see-agreementappointment-bishops.html [Accessed on November 15, 2019]

[10] Message of Pope Francis to the Catholics of China and to the Universal Church, 26.09.2018, Message of His Holiness Pope Francis to the Catholics of China and to the Universal Church, [Online] Available: http://press.vatican.va/content/salastampa/en/bollettino/ pubblico/2018/09/26/180926b.html [Accessed on November 15, 2019] 